\title{
T-cell involvement in drug-induced acute generalized exanthematous pustulosis
}

\author{
Markus Britschgi, ${ }^{1}$ Urs C. Steiner, ${ }^{1}$ Simone Schmid, ${ }^{1}$ Jan P.H. Depta, ${ }^{1}$ Gabriela Senti, ${ }^{2}$ \\ Andreas Bircher, ${ }^{3}$ Christoph Burkhart, ${ }^{1}$ Nikhil Yawalkar, ${ }^{1}$ and Werner J. Pichler ${ }^{1}$ \\ ${ }^{1}$ Clinic of Rheumatology and Clinical Immunology/Allergology, Inselspital, Bern, Switzerland \\ ${ }^{2}$ Department of Dermatology, University Hospital of Zürich, Zürich, Switzerland \\ ${ }^{3}$ Department of Dermatology, Kantonsspital Basel, Basel, Switzerland \\ Address correspondence to: Werner J. Pichler, Clinic of Rheumatology and Clinical Immunology/Allergology, PKT2 D572, \\ Inselspital, CH-3010 Bern, Switzerland. Phone: 41-31-632-22-64; Fax: 41-31-632-27-47; E-mail: werner.pichler@insel.ch. \\ Markus Britschgi and Urs C. Steiner contributed equally to this work.
}

Received for publication January 4, 2001, and accepted in revised form April 30, 2001.

\begin{abstract}
Acute generalized exanthematous pustulosis (AGEP) is an uncommon eruption most often provoked by drugs, by acute infections with enteroviruses, or by mercury. It is characterized by acute, extensive formation of nonfollicular sterile pustules on erythematous background, fever, and peripheral blood leukocytosis. We present clinical and immunological data on four patients with this disease, which is caused by different drugs. An involvement of T cells could be implied by positive skin patch tests and lymphocyte transformation tests. Immunohistochemistry revealed a massive cell infiltrate consisting of neutrophils in pustules and $\mathrm{T}$ cells in the dermis and epidermis. Expression of the potent neutrophil-attracting chemokine IL-8 was elevated in keratinocytes and infiltrating mononuclear cells. Drug-specific T cells were generated from the blood and skin of three patients, and phenotypic characterization showed a heterogeneous distribution of CD4/CD8 phenotype and of T-cell receptor $\mathrm{V} \beta$-expression. Analysis of cytokine/chemokine profiles revealed that IL-8 is produced significantly more by drug-specific $T$ cells from patients with AGEP compared with drug-specific $T$ cells from patients that had non-AGEP exanthemas. In conclusion, our data demonstrate the involvement of drug-specific $\mathrm{T}$ cells in the pathomechanism of this rather rare and peculiar form of drug allergy. In addition, they indicate that even in some neutrophil-rich inflammatory responses specific $\mathrm{T}$ cells are engaged and might orchestrate the immune reaction.
\end{abstract}

J. Clin. Invest. 107:1433-1441 (2001).

\section{Introduction}

Acute generalized exanthematous pustulosis (AGEP) is a rare disease that has been classified as pustular psoriasis von Zumbusch type for years. In 1968 Baker and Ryan were the first to assume that AGEP represents its own entity (1). Subsequently, this disorder was better characterized by Beylot et al. (2) and Roujeau et al. (3), who clarified its relationship to pustular psoriasis and assessed the place of drugs in its etiology.

The following features were found to be characteristic for AGEP: numerous, mostly nonfollicular intraepidermal or subcorneal pustules $(<5 \mathrm{~mm})$ arising on a widespread edematous erythema, fever above $38^{\circ} \mathrm{C}$, and blood neutrophils above $7 \times 10^{3} / \mu 1$. The onset of the disease is acute; resolution of pustules occurs spontaneously within fewer than 15 days (4).

Fever, elevated leukocyte counts, and appearance of multiple pustules tend to be associated with an acute bacterial infection, but AGEP is not due to bacterial pathogens as the content of the pustules is sterile. In a few cases the etiology of AGEP appears to be a viral infection (enterovirus or parvovirus B19) or a hypersensitivity reaction to mercury, but most cases of AGEP (90\%) have been described in association with the intake of drugs, in particular antibacterials such as aminopenicillins (4).

Adverse reactions to drugs manifest themselves in a variety of diseases, and the pathomechanism of some cutaneous adverse drug reactions may be of immunological origin $(5,6)$. Immune responses due to drug-specific $\mathrm{T}$ cells seem to be more relevant in certain cutaneous adverse drug reactions $(7,8)$. Such $\mathrm{T}$ cell-mediated sensitization to certain drugs has been detected by epicutaneous testing, lymphocytetransformation tests (LTTs), and generation of T-cell lines (TCLs) and clones (TCCs) (9-13). They are due to drugs such as aminopenicillins, which represent typical haptens able to covalently modify peptides and proteins $(13,14)$. However, cutaneous T-cell reactions might also be elicited by a direct recognition of drugs that bind to the MHC-peptide complex in a noncovalent way (15-17).

A neutrophilic inflammation as a manifestation of a drug allergic reaction - as in AGEP - is unusual, since eosinophilia, but not neutrophilia, is the typical hallmark of drug allergies $(12,18,19)$. Indeed, various studies have documented a high IL-5 production by tissueinfiltrating $T$ cells in exanthema as well as drug-specific 
T cells from the circulation $(19,20)$ and an enhanced eotaxin production by endothelial cells and infiltrating $T$ cells (19). Interestingly, previous studies in patients with AGEP have revealed a high rate of strongly positive patch tests to drugs compared with patients with other drug eruptions (21-24). This suggests that $\mathrm{T}$ cells are involved in AGEP as well. They may contribute to the accumulation of polymorphonuclear neutrophils (PMN) at the site of the lesions by the preferential release of PMN-attractive chemokines, mainly CXC chemokines such as IL-8 $(25,26)$.

To understand the function of T cells in AGEP patients we generated drug-specific TCLs and TCCs from the circulation and skin biopsy specimens and analyzed their phenotypes, specificities, and cytokine and chemokine profiles in vitro. Immunohistochemical analysis of the acute and patch-test lesions ex vivo was performed to determine the nature of the inflammatory cell infiltrate in vivo and to supplement the in vitro studies. The data point to an important role of drug-specific $T$ cells in AGEP, which clearly exert distinct functions compared with other cutaneous drug eruptions.

\section{Methods}

Patients. A summary of the patients' clinical characteristics is given in Table 1. Patient AP developed a generalized erythema after oral administration of Augmentin (amoxicillin and clavulanic acid; SmithKline Beecham Pharmaceuticals, Irvine, United Kingdom), which was given to treat an otitis media. She had fever $\left(40^{\circ} \mathrm{C}\right)$ and developed pustules on the back, arms, and face. She was then treated with antihistamines and local steroids. A similar pustulous reaction to the same drug had already occurred 5 years previously.

Patient JS developed generalized exanthema, pustules, and fever $\left(41^{\circ} \mathrm{C}\right)$ after intake of Clamoxyl (amoxicillin; Smith-Kline Beecham Pharmaceuticals) to treat a urinary tract infection. The patient required hospitalization in the intensive care unit. He had an adverse drug reaction (exanthema, no AGEP) to an unknown antibiotic 1 year before and once an angioedema of the tongue after administration of acetylsalicylic acid.

Patient AF received Cotrim (sulfamethoxazole and trimethoprim; Spirig, Basel, Switzerland) and later Klacid (clarithromycin; Abbott AG, Baar, Switzerland) to treat an upper respiratory tract infection. She developed generalized erythema, pustules, and fever $\left(41^{\circ} \mathrm{C}\right)$ and was hospitalized for 7 days in the unit for burn victims. No other drug allergies are known.

Patient EB was treated for the first time with Celebrex (celecoxib; Pfizer, Zürich, Switzerland) for periarthritis of the left shoulder. At the same time she was suffering from a viral infection (rhinitis). She developed a generalized erythema followed by pustules (face, shoulder) and fever $\left(38^{\circ} \mathrm{C}\right)$. She was treated with topical steroids. No other drug allergies are known.

Epicutaneous testing. Epicutaneous testing (patch test) was performed at least 2 months after recovery with PBS (negative control), Augmentin (half a pill of $375 \mathrm{mg} / 0.5$ ml PBS), Clamoxyl (375 mg/0.5 ml PBS), or Celebrex (one capsule containing $100 \mathrm{mg}$ celecoxib/0.5 ml PBS), respectively, as described in detail previously (27). Briefly, the freshly prepared drug/PBS mixtures were applied on the upper back using Al patch-test disks (Imal Pharmaceutica AG, Glarus, Switzerland). The test reactions were read at 48 hours and scored as recommended by the International Contact Dermatitis Research Group (28). No positive reactions to Augmentin and celecoxib were found in 19 controls, confirming the specificity of the patch test (data not shown).

Staining ofbiopsy specimens. Punch-biopsy specimens (5 $\mathrm{mm}$ ) were obtained from the acute lesions of patient $\mathrm{AF}$, fixed in $4 \%$ formalin, and routinely stained with hematoxylin and eosin (HE) for standard histology. In addition, immunohistochemistry was performed of skin biopsy specimens from the acute lesions as well as from the positive epicutaneous test reactions at 48 hours (patients AP and JS). The biopsy specimens were snapfrozen in tissue-embedding medium using isopentane precooled in liquid nitrogen and stored at $-80^{\circ} \mathrm{C}$.

Immunostaining for IL-5 and RANTES was performed using the alkaline phosphatase anti-alkaline phosphatase (APAAP) method (D0651; Diagnostics AG, Zug, Switzerland) and for CD4, CD8, CD25, human leukocyte antigen-DR (HLA-DR), neutrophil elastase, EG2, eotaxin, and IL-8 using the avidin-biotin complex/alkaline phosphatase method (K0376; Diagnostics AG), as described previously in detail $(8,19)$. Finally, all sections were developed in fuchsin substrate-chromogen (K0624; Diagnostics AG) and counterstained with hematoxylin (Haemalaun; Dr. Grogg Chemie AG, Stettlen, Switzerland). Substitution of the primary $\mathrm{Ab}$ with isotype-matched IgG and omission of the primary $\mathrm{Ab}$ served as negative controls.

Culture media. Culture medium (CM) consisted of RPMI-1640 (Sigma Chemical Co., St. Louis, Missouri, USA) supplemented with $10 \%$ pooled heat-inactivated human AB serum (Swiss Red Cross, Bern, Switzerland), $25 \mathrm{mM}$ HEPES buffer (Biochrom KG, Berlin, Germany), 2 mM L-glutamine (no. 663.710; Biotest AG, Dreieich, Germany), $10 \mu \mathrm{g} / \mathrm{ml}$ streptomycin, and 100 $\mathrm{U} / \mathrm{ml}$ penicillin (no. 4-01F00-H; Amimed Products AG, Allschwil, Switzerland). For the culture of TCLs or TCCs the CM was enriched $\left(\mathrm{CM}^{+}\right)$with $30 \mathrm{U} / \mathrm{ml}$ human recombinant IL-2 (rIL-2).

Epstein-Barr virus-transformed (EBV-transformed) B-lymphoblastoid cell lines (B-LCLs) were generated as described (29) and cultured in RPMI-1640 supplemented with 10\% FCS, 25 mM HEPES buffer, but without L-glutamine and without antibiotics.

Drugs and antigens. The following drugs were used for T-cell culture and proliferation assays: amoxicillin (Sigma Chemical Co.), clavulanic acid (Smith-Kline Beecham Pharmaceuticals), Celebrex capsules containing $200 \mathrm{mg}$ celecoxib (Pfizer), and sulfamethoxazole (SMX; Hoffmann-La Roche Ltd., Basel, Switzerland). Tetanus toxoid (TT; Serum and Vaccine Institute, Bern, Switzerland) was used as a control antigen. Stock solu- 
tions of each drug were always freshly prepared in CM just before use. Celecoxib and SMX were dissolved in RPMI-1640 with $0.05 \mathrm{M} \mathrm{NaOH}$.

Lymphocyte proliferation and generation of drug-specific T cells. Some $2 \times 10^{6}$ freshly isolated PBMCs from allergic patients were cultured for 6 days in $1 \mathrm{ml} \mathrm{CM}$ at $37^{\circ} \mathrm{C}$ in upright 12 ml-culture tubes (no. 3033; Falcon BD, Switzerland) in the presence of antigen. The following antigens and concentrations were used: amoxicillin, 200 and $500 \mu \mathrm{g} / \mathrm{ml}$; celecoxib, $0.1,1,10$, and $50 \mu \mathrm{g} / \mathrm{ml}$; SMX, 100 and $200 \mu \mathrm{g} / \mathrm{ml}$; TT, $10 \mu \mathrm{g} / \mathrm{ml}$. Then $0.5 \mu \mathrm{Ci}$ ${ }^{3} \mathrm{H}$-thymidine was added to the culture for 8-14 hours and radioactivity was measured by a $\beta$-counter (Packard Instrument Co., Meriden, Connecticut, USA) (12). Stimulation indices (SI) were calculated as cpm in culture with antigen divided by cpm in culture without antigen.

For generation of TCLs from PBMCs of patient AP, JS, and $\mathrm{EB}, 2 \times 10^{6}$ cells were cultured in $1 \mathrm{ml} \mathrm{CM}$ in 24-well plates with $500 \mu \mathrm{g} / \mathrm{ml}$ amoxicillin, $50 \mu \mathrm{g} / \mathrm{ml}$ celecoxib, or $200 \mu \mathrm{g} / \mathrm{ml} \mathrm{SMX}$, respectively. At day 7, rIL-2 was added, and after 14 days, bulk cultures were restimulated with autologous irradiated (45 Gy) PBMCs and the respective drug as antigen. Drug-specific TCLs were cloned by limiting dilution as described previously (20). Growing $\mathrm{T}$ cells were expanded in $\mathrm{CM}^{+}$and restimulated every 14 days with allogeneic PBMCs and phytohemagglutinin (PHA). In addition, TT-specific TCLs from patients AP and JS were generated to compare their functional activity with drug-specific TCCs.

To test the specificity of drug-specific TCLs and TCCs, $5 \times 10^{4} \mathrm{~T}$ cells were incubated at day $10-16$ after restimulation with either $5 \times 10^{4}$ of the respective irra- diated PBMCs or with $10^{4}$ autologous irradiated (60 Gy) B-LCLs as antigen-presenting cells (APCs) in the presence or absence of the indicated drug as antigen in $200 \mu \mathrm{l} \mathrm{CM}$ in U-bottom 96-well microplates. After 48 hours, ${ }^{3} \mathrm{H}$-thymidine incorporation of cultures was measured as indicated above. Cell cultures with SI greater than or equal to 2 were further expanded. Determination of HLA restriction of TCCs was done as described elsewhere (30).

Isolation of drug-specific T cells from epicutaneous test reactions. Some 5-mm punch-biopsy specimens were obtained after 48 hours from the positive epicutaneous test reactions of patients AP, JS, and EB (Table 1). Drugspecific $\mathrm{T}$ cells were isolated and cloned as described previously in detail (31). The isolated cells were cultured in U-bottom 96-well plates in a final volume of $100 \mu \mathrm{l} /$ well with $2.5 \times 10^{4}$ allogeneic irradiated PBMCs in CM enriched with $1 \mu \mathrm{g} / \mathrm{ml}$ PHA and $20 \mathrm{U} / \mathrm{ml} \mathrm{rIL-2}$ and expanded as described above.

Flow-cytometry analysis. Aliquots containing $10^{5}$ cells were stained with fluorochrome-conjugated $\mathrm{Ab}$ 's in 50 $\mu \mathrm{l}$ buffer $\left(\mathrm{PBS} / 1 \% \mathrm{FCS} / 0.02 \% \mathrm{NaN}_{3}\right)$ for $15-30$ minutes at $4{ }^{\circ} \mathrm{C}$. After two washings with buffer, cells were fixed (buffer plus 0.5\% paraformaldehyde) and then analyzed on a Coulter EPICS XL-MCL Flow Cytometer (Beckman Coulter Inc., Hialeah, Florida, USA). Monoclonality of generated TCCs was shown by T-cell receptor (TCR) V $\beta$-chain staining using fluorochrome-labeled anti-CD3 $\mathrm{mAb}$ (PharMingen/BD, Basel, Switzerland) and a panel of $22 \mathrm{mAb}$ 's recognizing different $\mathrm{V} \beta$ gene products detecting about $75 \%$ of all $V \beta$ families as described (20). Phenotype characterization and expres-

Table 1

Patients' characteristics

\begin{tabular}{|c|c|c|c|c|}
\hline & \multicolumn{4}{|c|}{ Patients } \\
\hline & AP & JS & $\mathrm{AF}$ & EB \\
\hline Age/sex & 30 years, $f$ & 60 years, $\mathrm{m}$ & 29 years, $f$ & 55 years, $f$ \\
\hline Recent drug intake & Amoxicillin and clavulanic acid & Amoxicillin & Sulfamethoxazole & Celecoxib \\
\hline $\begin{array}{l}\text { Interval between drug intake and: } \\
\text { - erythema } \\
\text { - formation of pustules }\end{array}$ & $\begin{array}{l}4 \text { hours } \\
3 \text { days }\end{array}$ & $\begin{array}{l}24 \text { hours } \\
3 \text { days }\end{array}$ & $\begin{array}{l}\text { Unknown } \\
30 \text { days }\end{array}$ & $\begin{array}{l}10 \text { days } \\
11 \text { days }\end{array}$ \\
\hline Previous drug reaction & Yes & Yes & No & No \\
\hline Duration of rash & 14 days & 14 days & 19 days & 8 days \\
\hline Fever $\left(>38^{\circ} \mathrm{C}\right)$ & Yes & Yes & Yes & Yes \\
\hline $\begin{array}{l}\text { Liver enzymes } \\
\quad \text { ASAT }(11-36 \mathrm{U} / \mathrm{I}) \\
\text { ALAT }(10-37 \mathrm{U} / \mathrm{I})\end{array}$ & $\begin{array}{l}\text { Not done } \\
\text { Not done }\end{array}$ & $\begin{array}{l}24 \\
40\end{array}$ & $\begin{array}{l}34 \\
80\end{array}$ & $\begin{array}{l}12 \\
10\end{array}$ \\
\hline $\begin{array}{l}\text { Blood cell count } \\
\text { Leukocytes }\left(10^{9} / \mathrm{I}\right) 3.2-9.0 \\
\text { Neutrophils }\left(10^{9} / \mathrm{I}\right) 1.6-7.2 \\
\text { Eosinophils }\left(10^{9} / \mathrm{I}\right) 0.02-0.4\end{array}$ & $\begin{array}{l}\text { Not done } \\
\text { Not done } \\
\text { Not done }\end{array}$ & $\begin{array}{c}27.1 \\
24.1 \\
1.3\end{array}$ & $\begin{array}{l}25.5 \\
23.2 \\
0.12\end{array}$ & $\begin{array}{c}15.2 \\
13.5 \\
0\end{array}$ \\
\hline $\mathrm{CRP}(<5 \mathrm{mg} / \mathrm{I})$ & Not done & 197 & 133 & 91 \\
\hline $\begin{array}{l}\text { Psoriasis in personal } \\
\text { and family history }\end{array}$ & No & No & No & No \\
\hline Patch test & Positive & Positive & Not done & Positive \\
\hline HLA type & $\begin{array}{c}\mathrm{A} 25(10) \mathrm{A} 33(19) \\
\mathrm{B} 50(21) \mathrm{B} 51(5) \\
\mathrm{DRB} 1 * 07 / 09\end{array}$ & $\begin{array}{l}\mathrm{A} 31(19) \mathrm{A} 68(28) \\
\mathrm{B} 62(15) \mathrm{B} 75(15) \\
\mathrm{DRB} 1 * 04 / \mathrm{X}\end{array}$ & $\begin{array}{l}\text { A1 A29(19) } \\
\text { B13 B44(12) } \\
\text { DR B1*07/X }\end{array}$ & $\begin{array}{c}\text { A11 A11 } \\
\text { B39(16) B44(12) } \\
\text { DR B1*07/13 }\end{array}$ \\
\hline
\end{tabular}

Characteristics of patients AP, JS, AF, and EB with AGEP are shown. ASAT, aspartic acid aminotransferase; ALAT, alanine aminotransferase; CRP, C-reactive protein. For liver enzymes, blood cell counts, and CRP, standard values are given. 
Table 2

Cytokine and chemokine secretion pattern of drug-specific blood- and skin-derived TCCs

\begin{tabular}{|c|c|c|c|c|c|c|c|c|c|}
\hline TCCs of & $\begin{array}{l}\text { Cutaneous adverse } \\
\text { drug reactions }\end{array}$ & $\begin{array}{l}\text { HLA-DR } \\
\text { typing }\end{array}$ & SI & $\begin{array}{c}\mathrm{IL}-4 \\
(\mathrm{pg} / \mathrm{ml})\end{array}$ & $\begin{array}{c}\mathrm{IL}-5 \\
(\mathrm{pg} / \mathrm{ml})\end{array}$ & $\begin{array}{c}\text { IFN- } \gamma \\
(\mathrm{pg} / \mathrm{ml})\end{array}$ & $\begin{array}{l}\text { RANTES } \\
(\mathrm{pg} / \mathrm{ml})\end{array}$ & $\begin{array}{l}\mathrm{GM}^{\mathrm{GM}} \mathrm{CSF}^{\mathrm{A}} \\
(\mathrm{pg} / \mathrm{ml})\end{array}$ & $\begin{array}{c}\mathrm{IL}-8^{\mathrm{B}} \\
(\mathrm{pg} / \mathrm{ml})\end{array}$ \\
\hline \multicolumn{10}{|c|}{ AGEP patients } \\
\hline AP S9 & AGEP & $07 / 09$ & $82.2(399)$ & 2,180 & 3,454 & 17,660 & 4,622 & 6,920 & 451 \\
\hline AP S15 & AGEP & $07 / 09$ & $57(372)$ & 100 & 5,520 & 337 & 540 & 1,930 & 121 \\
\hline AP S19 & AGEP & 07/09 & $52(691)$ & 1,630 & 11,530 & 32,540 & 4,731 & 10,124 & 573 \\
\hline AP S38 & AGEP & $07 / 09$ & $10.4(5,189)$ & $<1.1$ & 9,860 & 8,730 & 3,538 & 5,880 & 307 \\
\hline AP S39 & AGEP & $07 / 09$ & $24(567)$ & 34 & $<7.8$ & 14,520 & 1,106 & 2,966 & 69 \\
\hline AP S46 & AGEP & $07 / 09$ & $10(2,962)$ & 12 & $<7.8$ & 98,800 & 576 & 15,800 & 1,054 \\
\hline AP S47 & AGEP & $07 / 09$ & $5.5(3,960)$ & 120 & $<7.8$ & 80,900 & 2,276 & 12,740 & 1,286 \\
\hline AP B1 & AGEP & $07 / 09$ & $7.8(2,845)$ & 3,230 & 6,900 & 437,900 & 5,375 & 57,347 & 4,846 \\
\hline AP B6 & AGEP & $07 / 09$ & $7.1(2,352)$ & 630 & 537 & 330,358 & 1,566 & 25,490 & 1,619 \\
\hline AP B10 & AGEP & $07 / 09$ & $14.5(1,644)$ & 132 & 769 & 136,100 & 2,907 & 28,300 & 1,234 \\
\hline JS B7 & AGEP & $04 / X$ & $3.9(7,512)$ & 275 & 912 & 182,227 & 3,297 & 73,991 & 107 \\
\hline EB B27 & AGEP & $07 / 13$ & $47.9(217)$ & 14 & 431 & 30,990 & 2,403 & 3,670 & 2,782 \\
\hline \multicolumn{10}{|c|}{ Non-AGEP patients } \\
\hline OF B4 & Contact dermatitis & $15 / X$ & $204(43)$ & 172 & 5,190 & 686 & 1,738 & 2,503 & 16 \\
\hline UNO 9.5 & Exanthema & $01 / 10$ & $79.2(378)$ & 920 & 2,230 & 340,600 & 6,128 & 22,330 & 22 \\
\hline AB 10 & Bullous exanthema & $07 / 12$ & $315.3(135)$ & 1,600 & 5,740 & 8,700 & 2,622 & 4,036 & 47 \\
\hline AB 15 & Bullous exanthema & $07 / 12$ & $200.7(195)$ & 285 & 2,264 & 16,000 & 4,097 & 4,860 & 3 \\
\hline AB 39 & Bullous exanthema & $07 / 12$ & $245.7(220)$ & 820 & 15,390 & 15,730 & 2,466 & 7,347 & 38 \\
\hline AB 86 & Bullous exanthema & $07 / 12$ & $59.1(480)$ & $<1.1$ & 1,264 & 16,010 & 1,901 & 3,671 & 85 \\
\hline MBZ FB1 & Bullous exanthema & $11 / 15$ & $1,401.1(54)$ & 178 & 2,070 & 3,748 & 1,834 & 3,990 & 27 \\
\hline MBZ DB2 & Bullous exanthema & $11 / 15$ & $12.1(270)$ & 108 & 531 & 147,500 & 2,221 & 10,830 & 39 \\
\hline
\end{tabular}

Human IL-4, IL-5, IFN- $\gamma$, RANTES, GM-CSF, and IL-8 were measured by a sandwich ELISA in the supernatant of TCCs 48 hours after unspecific stimulation with anti-CD3 and anti-CD28 mAb. SI is given as cpm of stimulated culture divided by cpm of unstimulated culture. In parenthesis, cpm of background proliferation is given. Cytokine and chemokine amounts are given as difference between stimulated and unstimulated production in picograms per milliliter. Background of CM was always below detection level. $P$ value (Mann-Whitney $U$ test) is given for comparison of GM-CSF or IL- 8 production by AGEP patients versus non-AGEP patients. The median for GM-CSF production of AGEP patient-derived TCCs is $11,432 \mathrm{pg} / \mathrm{ml}$, for non-AGEP patient-derived TCCs is 4,448 $\mathrm{pg} / \mathrm{ml}$. The median for IL-8 production of AGEP patient-derived TCCs is $813.5 \mathrm{pg} / \mathrm{ml}$, for non-AGEP patient-derived TCCs is $32.5 \mathrm{pg} / \mathrm{ml}$. HLA-DR typing of the AGEP and non-AGEP patients are given. ${ }^{A} P>0.05 ;{ }^{B} P<0.025$.

sion of surface markers of TCLs and TCCs was performed using fluorochrome-labeled anti-CD3, antiCD4, anti-CD8, anti-CLA, anti-CD62L, and antiCXCR1 mAb's (all from PharMingen/BD) (20).

Cytokine and chemokine detection in cell-culture supernatants by ELISA. Some $5 \times 10^{5} \mathrm{~T}$ cells in $200 \mu \mathrm{l} \mathrm{CM}$ were stimulated for 48 hours in 96-well plates coated with anti-CD3 and soluble anti-CD28 $\mathrm{mAb}$ as costimulatory factor. To overcome unspecific production of cytokines and chemokines by PBMCs as APCs, TCCs were stimulated without addition of APCs. Supernatant of unstimulated $\mathrm{T}$ cells was taken as control, and proliferation was measured as described above. The following cytokine and chemokine ELISA sets were used: IL-5 and IL-8 (PharMingen, San Diego, California, USA); IFN- $\gamma$, and IL-4 (Diaclone, Besancon, France); RANTES and GM-CSF (R\&D Systems Europe Ltd., Abingdon, United Kingdom). The samples were diluted in duplicates $(1: 10,1: 100,1: 1000)$ and were measured according to standard protocols of the corresponding ELISA set. The detection limit of the assays performed was $1 \mathrm{pg} / \mathrm{ml}$ for IL-4, $8 \mathrm{pg} / \mathrm{ml}$ for IL-5, 13 $\mathrm{pg} / \mathrm{ml}$ for IFN- $\gamma, 1 \mathrm{pg} / \mathrm{ml}$ for RANTES, $15.6 \mathrm{pg} / \mathrm{ml}$ for GM-CSF, and $3 \mathrm{pg} / \mathrm{ml}$ for IL-8. Supernatant of cell-free anti-CD3/anti-CD28 mAb-treated wells showed no cross-reactivity or unspecific binding with the $\mathrm{mAb}$ of the ELISA sets (data not shown). Statistical analysis was performed using the Mann-Whitney $U$ test. $P$ values less than 0.05 were considered significant.

\section{Results}

Patients' characteristics. Table 1 summarizes the clinical characteristics of patients AP, JS, AF, and EB. They were classified as having AGEP in accordance with the criteria of Roujeau (4).

Table 1 also shows the results of HLA typing. One of the patients had the phenotype HLA-B51, which is thought to be more frequent in patients with AGEP (32). Interestingly, three of the patients had HLA-DR7, which has been associated with psoriasis (33). However, patient $\mathrm{AB}$ from the control group also has HLA-DR7, implying that HLA-DR7 alone is not responsible for AGEP development (Table 2).

Histology and immunophenotyping of acute lesions. A representative histology of an acute AGEP skin lesion is shown in Figure 1, a and b (patient AF). The main histopathological findings were subcorneal pustules, papillary edema, and a subepidermal lympho-histiocytic perivascular infiltrate with some polymorphonuclear neutrophils (PMNs) and eosinophils. Furthermore, necrosis of some keratinocytes was observed in the epidermis.

Phenotypic staining patterns of the inflammatory infiltrate are shown in Figure 1, c-f. Almost all cells within the intraepidermal pustules expressed neutrophil elastase. The perivascular infiltrate was composed mainly of T cells, of which $60-70 \%$ were $\mathrm{CD} 4^{+}$ and $30-40 \%$ were $\mathrm{CD}^{+}$. $\mathrm{EG}^{+}$eosinophils were found at about $5-10 \%$ of the cell infiltrate, while patient JS, 
who had also eosinophilia, had approximately $15-20 \%$ eosinophils. Furthermore, the lympho-histocytic infiltrate showed positive staining for the activation marker HLA-DR (80-90\%) and CD25 (10-15\%) (Figure 1, g and h). Interestingly, keratinocytes almost did not stain positive with the anti-HLA-DR Ab. Figure 1, i-l, shows a clear positive staining for IL-8 as well as a moderate positive staining for IL-5 in the epidermis, while RANTES and eotaxin were not clearly present in the epidermis. Staining for IL-8, IL-5, and to a lesser degree for RANTES and eotaxin was detected in the dermal cell infiltrate.

Drug-specific proliferation of patients' PBMCs. Dosedependent proliferative responses of PBMCs to the respective drug were observed in all four patients (Figure 2). These results confirm a strong T-cell sensitization for the three patients AP, JS, and AF to amoxicillin and SMX, respectively (SI between 3.4 to 8.3 ) and a weak T-cell sensitization for EB to celecoxib (SI: 2.3).

$T$ cells isolated from PBMCs are drug-specific. In total, 1,244 TCLs and TCCs were generated from PBMCs of patients AP, JS, and EB. Some 27 amoxicillin-specific TCLs and TCCs were obtained from patients AP and JS (SI: 2.0-13.9) and 30 celecoxib-specific from patient EB (SI: 2.0-56.5). We analyzed extensively for a potential cross-reactivity between the two sulfonamides celecoxib and SMX. PBMCs and more than 200 SMX-specific TCCs from a SMX-allergic patient and PBMCs of EB did not reveal any cross-reactivity (data not shown). This suggests that the sulfonamide structure per se does not account for $T$ cell-mediated cross-reactivity. Figure 3, a-e, shows the specificity and the phenotype of some selected blood-derived TCLs and TCCs, and Figure 3, f-g, illustrates the dose-dependent proliferation of three representative TCCs. The TCLs and TCCs were $\mathrm{CD} 4^{+}$or $\mathrm{CD} 8^{+}$, and all expressed the $\alpha \beta$ TCR. Immunofluorescence staining revealed a distinct $\mathrm{V} \beta$-chain usage of the TCCs. This heterogeneity in the TCR V $\beta$ of TCCs suggests the lack of oligoclonality of the drug-specific T-cell response.

$T$ cells isolated from positive epicutaneous test reactions are drug-specific. To further prove the involvement of drugs in eliciting AGEP, we performed patch tests in patients $\mathrm{AP}, \mathrm{JS}$, and EB. In agreement with previous reports (7, 21-23), application of the drug resulted in erythema, induration, and vesicle formation (Figure $4, \mathrm{a}-\mathrm{f}, \mathrm{h}$ ) in all three patients.

Forty-eight hours after drug application, biopsies from positive epicutaneous test reactions were obtained and divided into two equal parts. One part served to elute drug-specific $\mathrm{T}$ cells (Figure $3, \mathrm{~d}$ and e), and the second part was used to analyze the cell infiltration by immunohistochemistry (Figure $4, \mathrm{a}-\mathrm{n}$ ).

A total of 94 TCLs and TCCs were generated from skin-biopsy specimens of patient AP, of which 27 were specific for amoxicillin (SI: 2.0-13.8) (Figure 3d). All skin-derived $\mathrm{T}$ cells of patient $\mathrm{AP}$ reacted to the drug in the presence of autologous PBMCs, but not B-LCLs. Phenotype characterization revealed that TCLs of patient $\mathrm{AP}$ were mainly $\mathrm{CD} 4^{+}$; however, some $\mathrm{CD} 8^{+}$ TCLs were found as well. All TCCs were $\mathrm{CD} 4^{+}$.

We also gained 283 TCLs from the positive epicutaneous skin test of patient JS. Some 22 of them were amoxicillin-specific (SI: 2.0-43.4) (Figure 3e). Ten were $\mathrm{CD}^{+}$, four $\mathrm{CD}^{+}$, and eight TCLs consisted of a $\mathrm{CD}^{+} / \mathrm{CD}^{+}{ }^{+}$T-cell mixture. TCLs and TCCs from patient AP and JS expressed the $\alpha \beta$ TCR.

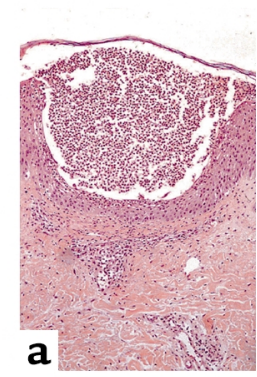

HE

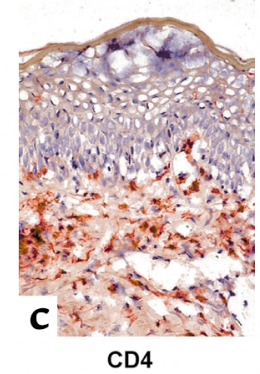

CD4
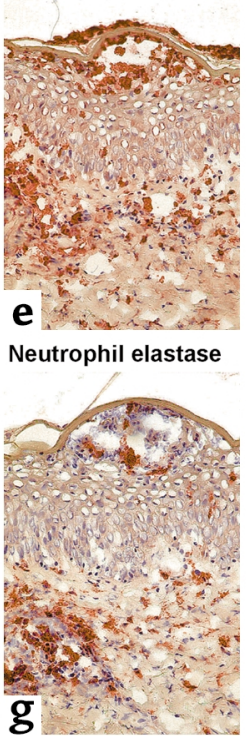

HLA-DR

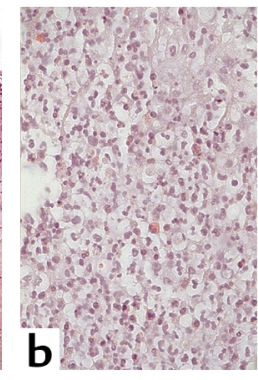

HE

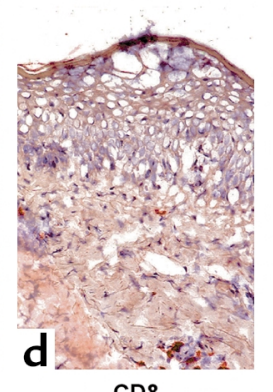

CD8

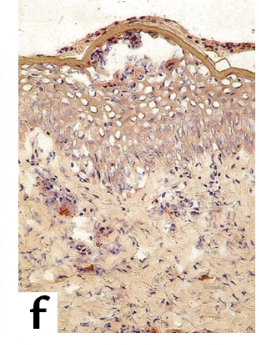

EG2

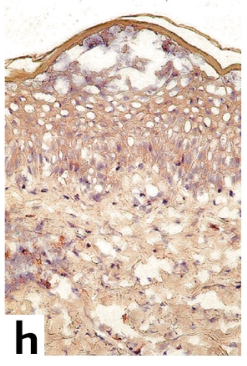

CD25

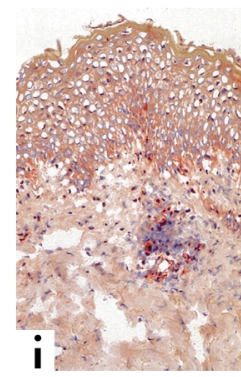

IL-5

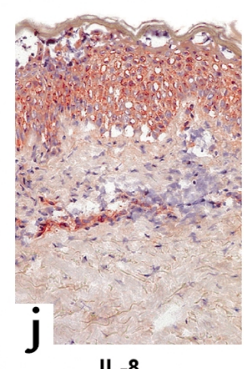

IL-8

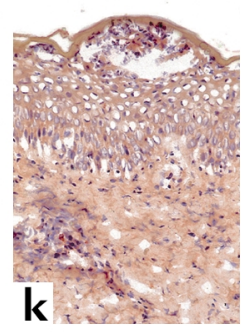

Eotaxin

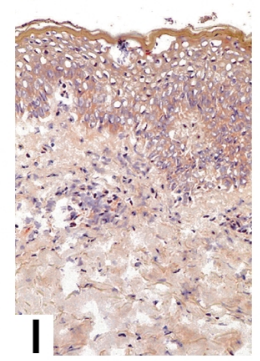

RANTES

\section{Figure 1}

Representative immunohistochemistry of acute skin-biopsy specimens of patient AF. (a and $\mathbf{b}$ ) Staining of acute AGEP skin lesion with $\mathrm{HE}$ is shown. (a) $\times 100$. (b) $\times 400$. For immunophenotyping of acute lesions stainings of (c) CD4, (d) CD8, (e) neutrophil elastase, and (f) eosinophil marker EG2 are demonstrated. Activation of infiltrating cells and tissue is shown by (g) HLA-DR and by (h) CD25 staining. (i-I) Cytokine and chemokine production is shown for IL-5, IL-8, eotaxin, or RANTES. (c-I) $\times 250$. 
Figure 2

Drug-specific proliferation of patients' PBMCs in a lymphocyte transformation test. PBMCs $\left(2 \times 10^{6}\right)$ of patients were coincubated with different drugs for 6 days. Proliferation was then detected by ${ }^{3} \mathrm{H}$-thymidine incorporation. Drugs administered were: patients AP and JS, amoxicillin; patient $A F, S M X$; patient $E B$, celecoxib. SI is given as cpm of stimulated culture divided by cpm of unstimulated culture.

Patient EB also showed positive epicutaneous test reaction to celecoxib. Some 30 TCLs (all CD4 $4^{+}$) could be generated from the skin biopsy but were not specific to celecoxib. The TCR was not further characterized.

Cytokine/chemokine production and IL-8 receptor expression of drug-specific TCCs. Cytokine and chemokine expression were measured in the supernatant of stimulated TCCs by a sandwich ELISA 48 hours after stimulation. We analyzed ten TCCs of patient AP (seven skin derived and three blood derived), one TCC of patient JS (blood derived), and one TCC of patient EB (blood derived). Table 2 shows that drug-specific TCCs from patients AP, JS, and EB (AGEP patients) produce variable amounts of cytokines/chemokines.

This cytokine/chemokine profile (IL-4, IL-5, IFN- $\gamma$, RANTES, and GM-CSF) was similar to the one obtained with TCCs from patients with other drug allergies (Table 2, non-AGEP patients). However, TCCs from AGEP patients showed a tendency to produce higher amounts of GM-CSF, but it was not significant

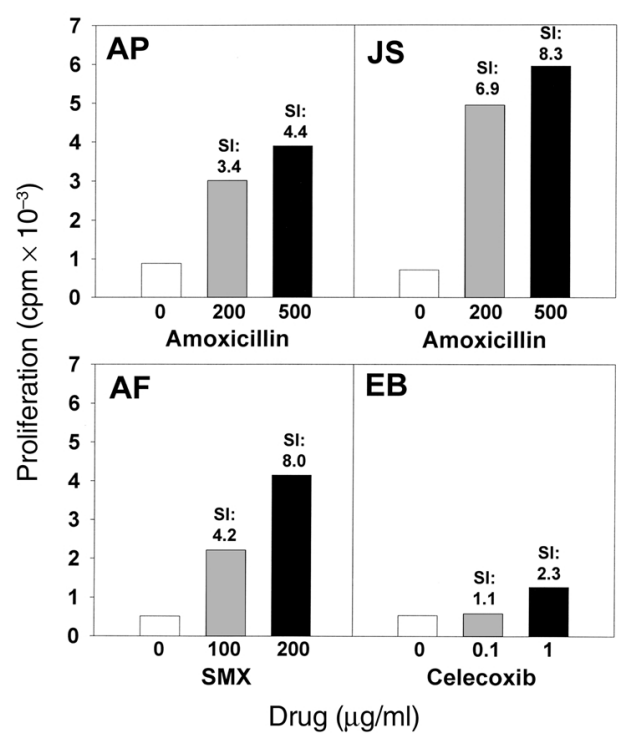

$(P>0.05$; Mann-Whitney $U$ test). Some $25 \%$ of TCCs of AGEP patients produced low amounts of IL-8 (S15 and S39 of patient AP and B7 of patient JS; 69-121 $\mathrm{pg} / \mathrm{ml})$. However, $75 \%$ of TCCs produced relatively high levels of IL-8 (307-4,846 pg/ml). A comparison of the IL-8 production of the 12 AGEP (mean 1,204 $\mathrm{pg} / \mathrm{ml}$ ) with the ten non-AGEP TCCs (mean $34 \mathrm{pg} / \mathrm{ml}$ ) gave a significantly higher IL-8 production by AGEP TCCs $(P<0.025$, Mann-Whitney $U$ test). This highly
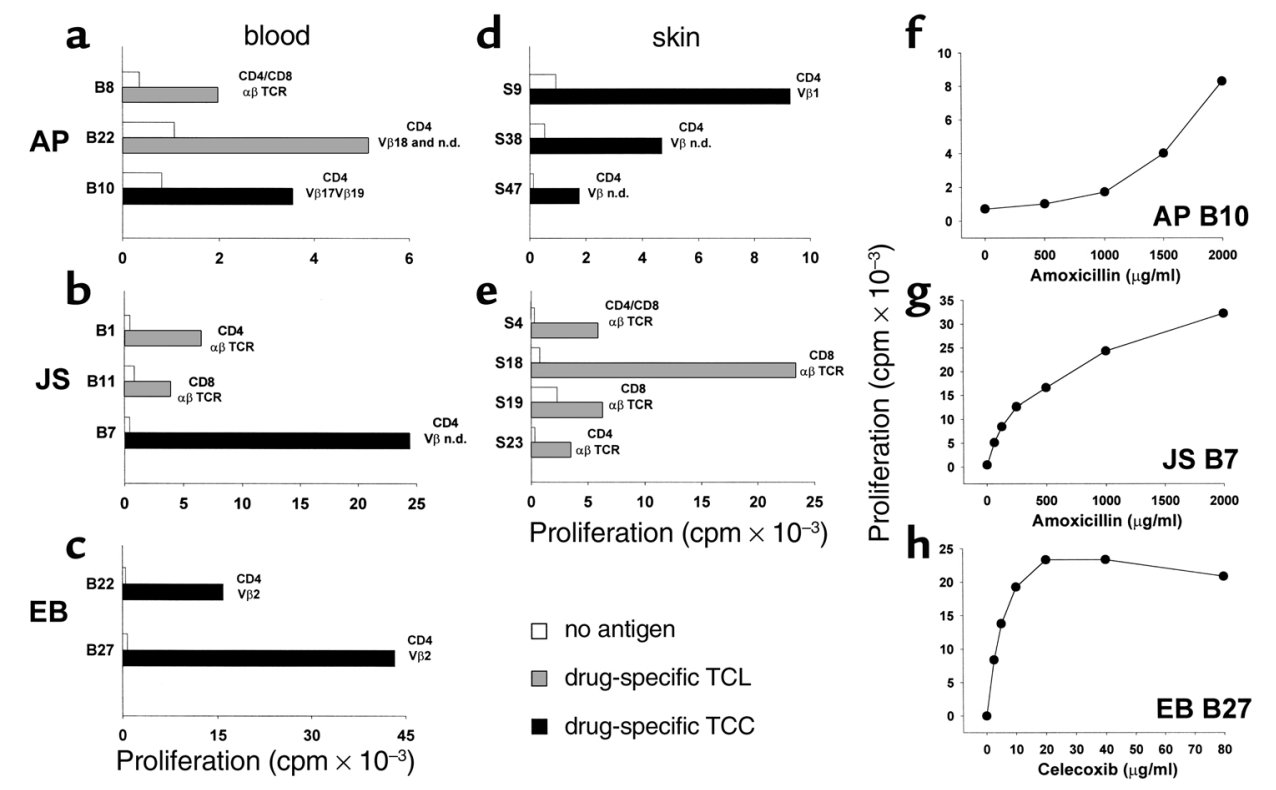

Figure 3

Specificity and dose response of drug-specific T cells. The specificity and phenotype characterization of selected blood-derived (a-c) and skin-derived ( $\mathbf{d}$ and $\mathbf{e}$ ) TCLs (shaded bars) and TCCs (filled bars) from patient AB, JS, and EB, and dose-dependent proliferative response of three TCCs $(\mathbf{f}-\mathbf{h})$ to respective drugs are shown. T cells $\left(5 \times 10^{4}\right)$ were incubated with autologous irradiated PBMCs $\left(5 \times 10^{4}\right)$ or B-LCLs $\left(10^{4}\right)$ as APCs in the presence or absence of drugs (AP and JS, T cells with amoxicillin $500 \mu \mathrm{g} / \mathrm{ml} ; \mathrm{EB}, \mathrm{T}$ cells with celecoxib $10 \mu \mathrm{g} / \mathrm{ml}$ ). ${ }^{3} \mathrm{H}$-thymidine uptake was measured after 48 hours. Phenotype characterization of CD4, CD8, TCR, and V $\beta$ chain distribution was analyzed by flow cytometry. $T$ cells that were not analyzed for their $\mathrm{V} \beta$ chain were considered to be TCL. $T$ cells that expressed one $V \beta$ chain (or two simultaneously) or that had no V $\beta$ chain detectable by the mAb used (V $\beta$ n.d., not detectable) were considered to be TCCs. For dose response AP B10 (f) and JS B7 (g) were incubated with amoxicillin and EB B27 with celecoxib (h) in the presence of B-LCLs as APCs. 
elevated IL-8 production seems to be related to the stimulatory antigen. TT-specific TCLs from AGEP patients AP and JS and TT-specific TCCs from nonAGEP patients did not produce detectable IL-8 levels after specific (TT) or nonspecific (anti-CD3/anti$\mathrm{CD} 28 \mathrm{mAb}$ ) stimulation, although they were DR4 or DR7 restricted, respectively (data not shown).

We also analyzed for the expression of CXCR1, one of the two IL-8 receptors. CXCR1 was found to be highly expressed (51-71\%) by drug-specific TCCs from AGEP patients that also produce high amounts of IL-8, but is expressed to a lower extent (20-37\%) by TCCs and TCLs that produce low or no IL-8 $(P<0.05$, Mann-Whitney $U$ test).

Immunohistochemistry of biopsy specimens from positive epicutaneous test reactions. Immunohistochemical analysis from biopsy specimens of positive epicutaneous test reactions at 48 hours are shown in Figure 4, a-n (patient JS). The mononuclear cell infiltrate was composed mainly of T cells (50-70\%). About two thirds of the $\mathrm{T}$ cells expressed CD4 (Figure 4a), whereas approximately one third were $\mathrm{CD}^{+}$(Figure $4 \mathrm{~b}$ ). PMNs as well as EG2 ${ }^{+}$eosinophils were scattered throughout the skin sections (Figure 4, c and d), representing about $10-15 \%$ and $5-10 \%$ of the cell infiltrate, respectively. Interestingly, at the time of the biopsy the vesicles were not filled with PMNs but contained mainly $\mathrm{CD} 4^{+} \mathrm{T}$ cells (Figure 4, $a$ and $b$ ). Ninety to one hundred percent of the cell infiltrate strongly expressed HLA-DR, while the keratinocytes were practically not positively stained for HLA-DR (Figure 4e). About $10-15 \%$ of the infiltrating cells expressed CD25 (Figure 4f).

In immunohistochemical studies with anti-IL-5, anti-IL-8, anti-eotaxin, and anti-RANTES, only a few positive cells were detectable in healthy skin (Figure 4, $\mathrm{g}, \mathrm{i}, \mathrm{k}$, and $\mathrm{m}$ ). In contrast, in the patchtest samples of patient JS strong expression of IL-8, RANTES, and, to a lesser degree, eotaxin was found, particularly in the basal cell layer of the epidermis and in the endothelial cells of the dermis (Figure $4, \mathrm{j}, 1$, and $\mathrm{n}$ ). Furthermore, positive staining for IL-5, RANTES, IL-8, and, to a less- er degree, eotaxin was detected in the cell infiltrate (Figure 4, h, j, l, and n).

Similar staining patterns with a high expression of IL-8 and lower expression of eotaxin and RANTES, together with lower numbers of eosinophils, were also observed in biopsy specimens of patient AP (data not shown).

\section{Discussion}

In this study we present clinical and immunological data for four patients with AGEP, which address the immunological background of this drug-allergic disease and clarify the involvement of T cells in AGEP. All four patients fulfilled the criteria of AGEP (3), and the histology of the acute lesion was typical: subcorneally localized neutrophilic pustules and accumulation of $\mathrm{T}$ cells perivascularly and around the pustules.

The crucial role of $\mathrm{T}$ cells in AGEP could be confirmed by distinct means: all four patients showed a positive in vitro proliferative response of $\mathrm{T}$ cells to the incriminated drug. Other individuals exposed to these drugs without side effects were negative in this assay 
(ref. 7 and authors' observation). The most convincing proof for a drug-specific T-cell stimulation in this particular disease comes from the analysis of the positive patch-test reaction of the three patients tested (AP, JS, EB). Drug-specific proliferation and skin infiltration by $T$ cells could be proven by generating drug-specific TCLs and TCCs from primary cell cultures and from biopsy specimens of positive epicutaneous test reactions at 48 hours. In addition, histology revealed activated (HLA-DR ${ }^{+}$or $\mathrm{CD} 25^{+}$) CD4 and CD8 cell infiltration in the dermis and epidermis, vesicle formation, and some eosinophilia. The somewhat stronger T-cell response in patch-test reactions, compared with the acute drug allergy, might be due to the higher local drug concentration in the skin test.

The TCCs recognized the drug in an HLA-DR-restricted way, although not all reacted in an allele-restricted way (data not shown) (30). All drug-reactive $\mathrm{T}$ cells had the $\alpha \beta$ TCR phenotype and were mainly $\mathrm{CD}^{+}$. In addition, $\mathrm{CD}^{+} \mathrm{T}$ cells also appear to be involved in this peculiar drug reaction because they were present within the drug-specific TCLs and could be observed in the immunohistology of the acute as well as of the patch-test lesions (up to $30 \%$ activated $\mathrm{CD}^{+} \mathrm{T}$ cells). However, until now we were unsuccessful in cloning these $\mathrm{CD} 8^{+} \mathrm{T}$ cells.

The TCR V $\beta$ analysis after 7 and 10 days of primary culture did not indicate an oligoclonality (data not shown), and the few TCCs obtained indeed had a distinct usage of TCR V $\beta$. This is in agreement with previous observations on drug-specific T-cell reactions (34), although occasionally an oligoclonal outgrowth has been observed in some patients $(20,35,36)$. This suggests that the drug can be presented in various ways, giving rise to distinct antigenic determinants, or that different TCRs can recognize the same antigenic determinant formed by the MHC-drug complex.

The function of the drug-specific $\mathrm{T}$ cells from patients with AGEP seem to be heterogeneous: As in other drug-induced reactions, the degree of either CD4 or CD8 cell involvement, as well as the degree of activating $\mathrm{CD} 4^{+} \mathrm{T}$ cells with distinct functions (cytokine production), might determine the clinical picture (37, 38). In AGEP, immunohistology as well as the characterization of TCCs revealed evidence for production of the potent PMN-attractive chemokine IL-8 by keratinocytes and drug-specific $\mathrm{CD}^{+} \mathrm{T}$ cells. Neither the IL-8 production by T cells nor the PMN infiltration is seen to such an extent in other forms of drug allergy, e.g., maculopapular drug eruptions (19). Thus, IL8-producing T cells seem to be rather typical for AGEP, and they could - together with their relatively strong production of GM-CSF - contribute to the recruitment of PMN into the epidermis. Moreover, the local IL-8 production might contribute to the recruitment of further IL-8-producing T cells, because they express high levels of CXCR1.

Although some infiltrating T cells synthesize IFN- $\gamma-$ a finding confirmed by ELISA measurements of drugactivated TCCs derived from the skin or the circulation (data not shown) - keratinocytes did not or only moderately express MHC class II. Most likely, the IFN- $\gamma$ production by the infiltrating $\mathrm{T}$ cells was insufficient to induce MHC class II expression on tissue cells, or other factors necessary for MHC class II upregulation by keratinocytes were missing. This is clearly in contrast to the high MHC class II expression in patients with maculopapular drug eruption (8).

The eosinophilia in one particular patient (JS) was probably due to the high IL-5 expression by infiltrating $\mathrm{T}$ cells, as well as to the rather strong eotaxin and RANTES expression by perivascular cells, while in the other patients practically no eotaxin-positive cells were found. This is in accordance with observations of Roujeau et al., where eosinophilia is seen in about $30 \%$ of patients with AGEP (3).

Epicutaneous drug application by patch test also induced some PMN infiltration into the epidermis and a rather strong IL-8 expression by keratinocytes, but the vesicles contained - in contrast to the acute reaction - only few PMN, but mainly $\mathrm{CD}^{+}$and some $\mathrm{CD}^{+} \mathrm{T}$ cells. As another report on patch-test reaction of AGEP patients describes pustule formation after longer skin test application (96 hours) (22), the biopsy that was taken at 48 hours might reflect the early events. This would suggest that the drug-specific $\mathrm{CD}^{+}$ (and probably also some $\mathrm{CD} 8^{+}$) $\mathrm{T}$ cells are reacting first, and they may be responsible for vesicle formation. PMNs immigrate later to fill the vesicles and transform them to pustules. The patch-test reaction appears to nicely mirror the events of an acute AGEP reaction. This shows that the once-generated immune response to a drug in AGEP patients is persistent and does not change on subsequent drug exposures, which can occur via the skin or by the oral route. We believe that this is due to a particular priming of drug-specific $T$ cells in AGEP, which react in the same way to drug re-exposure. The reproducibility of the rather rare systemic drug allergy in a skin-test reaction opens the possibility of better analyzing these allergic diseases, even in vivo, which is particularly important because animal models do not exist.

What is priming $\mathrm{T}$ cells in favor of more IL-8 production in patients with AGEP is unclear at present. Indeed, it is a puzzling aspect of drug allergy that the same drug (i.e., amoxicillin or SMX) can elicit quite distinct immunological reactions leading to different diseases, such as anaphylaxis, maculopapular drug eruption, bullous skin disease, interstitial lung disease, etc. Drugs are peculiar antigens because they can bind to and modify soluble or cell-bound molecules such as MHC class II or I molecules and, in particular, their embedded peptides (39). The clinical and immunological heterogeneity of drug allergy may be the result of drugs binding to distinct immunogenic peptides, or to distinct MHC molecules, or to other molecules involved in the immune response (cytokine receptors, adhesion molecules, etc.). In this context, the rather frequent presence in the affected population of the HLA- 
$D R B 1 * 07$ allele - which is, interestingly enough, also associated with psoriasis (33) - must be explored.

Another reason for the enhanced IL-8 production might be a peculiar drug presentation, which could lead to distinct signals and T-cell functions. Drugs can be presented covalently bound to the peptide/MHC complex (i.e., amoxicillin) or in a rather labile, noncovalent way (i.e., SMX) $(15,16)$. However, both presentations appear to be able to elicit an AGEP-related $\mathrm{T}$-cell response because celecoxib was presented in a labile way, without requirement of drug processing or metabolism (data not shown) and two patients reacted to the covalently binding drug amoxicillin.

In conclusion, AGEP appears to be a disease where a cell-bound drug presentation elicits a drug-specific CD4 and CD8 immune reaction, which results in a preferential IL-8 production by $\mathrm{T}$ cells. Other immune reactions, i.e., IL-5 production by $\mathrm{T}$ cells, can occur simultaneously as well and contribute to the slightly different clinical picture in each patient. Further work is required to better understand the interplay of $\mathrm{T}$ cells with other cells, in particular keratinocytes, which seem to have an important role in AGEP by expressing PMNand eosinophil-attracting chemokines. It is tempting to speculate that the elucidation of this new pathogenic mechanism involving $T$ cells and neutrophils may not only help avoid such side effects of drug therapy, but may also provide a clue to further our understanding of similar diseases (i.e., pustular psoriasis).

\section{Acknowledgments}

This work was supported by grant 31-61452.00 of the Swiss National Science Foundation (to W.J. Pichler). We are grateful to the patients AP, JS, AF, and EB for their collaboration in this study. We thank M. Hurni for transferring patient JS, S. von Greyerz for help in T-cell cloning, J. Tilch and I. Strasser for their excellent technical assistance, and I. Hunziker and D.J. Naisbitt for critical reading of the manuscript.

1. Baker, H., and Ryan, T. 1968. Generalized pustular psoriasis. A clinical and epidemiological study of 104 cases. Br. J. Dermatol. 80:771-793.

2. Beylot, C., Bioulac, P., and Doutre, M.S. 1980. Poustuloses exanthématiques aïgues généralisées. A propos de 4 cas. Ann. Dermatol. Venereol. 107:37-48.

3. Roujeau, J., Bioulac-Sage, P., and Bourseau, C. 1991. Acute generalized exanthematous pustulosis: analysis of 63 cases. Arch. Dermatol. 127:1333-1338.

4. Roujeau, J.C. 2000. Neutrophilic drug eruptions. Clin. Dermatol. 18:331-337.

5. Griem, P., Wulferink, M., Sachs, B., Gonzalez, J., and Gleichmann, E. 1998. Allergic and autoimmune reactions to xenobiotics: how do they arise? Immunol. Today. 19:133-141.

6. Pichler, W.J., Schnyder, B., Zanni, M.P., Hari, Y., and von Greyerz, S. 1998. Role of T cells in drug allergies. Allergy. 53:225-232.

7. Schnyder, B., and Pichler, W.J. 2000. Skin and laboratory tests in amoxicillin- and penicillin-induced morbilliform skin eruption. Clin. Exp. Allergy. 30:590-595.

8. Yawalkar, N., et al. 2000. Infiltration of cytotoxic T cells in drug-induced cutaneous eruptions. Clin. Exp. Allergy. 30:847-855.

9. Koponen, M., Pichler, W.J., and de Weck, A.L. 1986. T cell reactivity to penicillin: phenotypic analysis of in vitro activated cell subsets. J. Allergy Clin. Immunol. 78:645-652.

10. Nyfeler, B., and Pichler, W.J. 1997. The lymphocyte transformation test for the diagnosis of drug allergy: sensitivity and specificity. Clin. Exp. Allergy. 27:175-181.
11. Barbaud, A., Reichert-Penetrat, S., and Tréchot, P. 1998. The use of skin testing in the investigation of cutaneous adverse drug reactions. Br. J. Dermatol. 139:49-58.

12. Mauri-Hellweg, D., et al. 1995. Activation of drug-specific CD4+ and CD8+ $\mathrm{T}$ cells in individuals allergic to sulfonamides, phenytoin, and carbamazepine. J. Immunol. 155:462-472.

13. Brander, C., et al. 1995. Heterogeneous T cell responses to beta-lactammodified self-structures are observed in penicillin-allergic individuals. $J$. Immunol. 155:2670-2678.

14. Padovan, E., Mauri-Hellweg, D., Pichler, W.J., and Weltzien, H.U. 1996. T cell recognition of penicillin $\mathrm{G}$ : structural features determining antigenic specificity. Eur. J. Immunol. 26:42-48.

15. Schnyder, B., Mauri-Hellweg, D., Zanni, M., Bettens, F., and Pichler, W.J. 1997. Direct, MHC-dependent presentation of the drug sulfamethoxazole to human alphabeta T cell clones. J. Clin. Invest. 100:136-141.

16. Zanni, M.P., et al. 1998. HLA-restricted, processing- and metabolism-independent pathway of drug recognition by human $\alpha \beta$ T lymphocytes. J. Clin. Invest. 102:1591-1598.

17. Schnyder, B., et al. 2000. Recognition of sulfamethoxazole and its reactive metabolites by drug-specific CD4+ T cells from allergic individuals. $J$. Immunol. 164:6647-6654.

18. Pichler, W.J., et al. 1997. High IL-5 production by human drug-specific T cell clones. Int. Arch. Allergy Immunol. 113:177-180.

19. Yawalkar, N., et al. 2000. Evidence for a role of IL-5 and eotaxin in activating and recruiting eosinophils in drug-induced cutaneous eruptions. $J$. Allergy Clin. Immunol. 106:1171-1176.

20. Zanni, M.P., et al. 1997. Characterization of lidocaine-specific T cells. J. Immunol. 158:1139-1148.

21. Wolkenstein, P., et al. 1996. Patch-testing in severe cutaneous adverse drug reactions including Stevens-Johnson syndrome and toxic epidermal necrolysis. Contact Dermatitis. 35:234-236.

22. Demitsu, T., et al. 1996. Acute generalized exanthematous pustulosis induced by dexamethasone injection. Dermatology. 193:56-58.

23. Jan, V., et al. 1998. Acute generalized exanthematous pustulosis induced by dilitiazem: value of patch testing. Dermatology. 197:274-275.

24. Kempinaire, A., et al. 1997. Terbinafine-induced acute generalized exanthematous pustulosis confirmed by a positive patch-test result. J. Am. Acad. Dermatol. 37:653-655.

25. Schröder, J.M., Mrowietz, U., Morita, E., and Christophers, E. 1987. Purification and partial biochemical characterization of a human monocytederived, neutrophil-activating peptide that lacks interleukin 1 activity. $J$. Immunol. 139:3474-3483.

26. Baggiolini, M., Walz, A., and Kunkel, S.L. 1989. Neutrophil-activating peptide-1/interleukin 8 , a novel cytokine that activates neutrophils. J. Clin. Invest. 84:1045-1049.

27. Yawalkar, N., Helbling, A., Pichler, C.E., Zala, L., and Pichler, W.J. 1999. T cell involvement in persulfate triggered occupational contact dermatitis and asthma. Ann. Allergy Asthma Immunol. 82:401-404.

28. Wilkinson, D.S., et al. 1970. Terminology of contact dermatitis. Acta Derm. Venereol. 50:287-292.

29. Wyss-Coray, T., et al. 1993. Antigen-presenting human T cells and antigenpresenting B cells induce a similar cytokine profile in specific $\mathrm{T}$ cell clones. Eur. J. Immunol. 23:3350-3357.

30. Zanni, M.P., von Greyerz, S., Schnyder, B., Wendland, T., and Pichler, W.J. 1998. Allele-unrestricted presentation of lidocaine by HLA-DR molecules to specific $\alpha \beta+\mathrm{T}$ cell clones. Int. Immunol. 10:507-515.

31. Yawalkar, N., et al. 2000. T cells isolated from positive epicutaneous test reactions to amoxicillin and ceftriaxone are drug-specific and cytotoxic. J. Invest. Dermatol. 115:647-652.

32. Bernard, P., Lizeveaux-Parneix, V., Miossec, V., Bonnetblanc, J.M., and Drouet, M. 1995. HLA et prédisposition génétique dans les pustuloses exanthématiques aiguës généralisées (PEAG) et dans les exanthèmes maculo-papuleux (EMP). Ann. Dermatol. Venereol. 122(Suppl.):S38-S39.

33. Ikaheimo, I., Silvennoinen-Kassinen, S., Karvonen, J., Jarvinen, T., and Tiilikainen, A. 1996. Immunogenetic profile of psoriasis vulgaris: association with haplotypes A2,B13,Cw6,DR7,DQA1*0201 and A1,B17,Cw6,DR7,DQA1*0201. Arch. Dermatol. Res. 288:63-67.

34. von Greyerz, S., et al. 1999. Interaction of sulfonamide derivatives with the TCR of sulfamethoxazole-specific human $\alpha \beta+\mathrm{T}$ cell clones. J. Immunol. 162:595-602.

35. Mauri-Hellweg, D., et al. 1996. Cross-reactivity of T cell lines and clones to beta-lactam antibiotics. J. Immunol. 157:1071-1079.

36. Vollmer, J., Fritz, M., Dormoy, A., Weltzien, H.U., and Moulon, C. 1997. Dominance of the BV17 element in nickel-specific human T cell receptors relates to severity of contact sensitivity. Eur. J. Immunol. 27:1865-1874.

37. Hertl, M., and Merk, H.F. 1995. Lymphocyte activation in cutaneous drug reactions. J. Invest. Dermatol. 105(Suppl.):95S-98S.

38. Schnyder, B., et al. 1998. T-cell-mediated cytotoxicity against keratinocytes in sulfamethoxazol-induced skin reaction. Clin. Exp. Allergy. 28:1412-1417.

39. Martin, S., and Weltzien, H.U. 1994. T cell recognition of haptens, a molecular view. Int. Arch. Allergy Immunol. 104:10-16. 